\title{
The hippocampal debate: are we asking the right questions?
}

\author{
A. David Redish \\ Department of Neuroscience, University of Minnesota, 6-145 Jackson Hall, Minneapolis, MN 55455, USA
}

Received 29 January 2001; received in revised form 11 July 2001; accepted 25 July 2001

\begin{abstract}
For years, the debate has been: 'Is the hippocampus the cognitive map?' or 'Is the hippocampus the core of memory?' These two hypotheses derived their original power from two key experiments - the cognitive map theory from the remarkable spatial correlates seen in recordings of hippocampal pyramidal cells and the memory theory from the profound amnesias seen in the patient H.M. Both of these key experiments have been reinterpreted over the years: hippocampal cells are correlated with much more than place and H.M. is missing much more than just his hippocampus. However, both theories are still debated today. The hippocampus clearly plays a role in both navigation and memory processing. The question that must be addressed is rather: 'What is the role played by the hippocampus in the navigation and memory systems?' By looking at the navigation system as a whole, one can identify the major role played by the hippocampus as correcting for accumulation errors that occur within idiothetic navigation systems. This is most clearly experimentally evident as reorientation when an animal is lost. Carrying this over to a more general process, this becomes a role of recalling a context, bridging a contextual gap, or, in other words, it becomes a form of recognition memory. I will review recent experimental data which seems to support this theory over the more general spatial or memory theories traditionally applied to hippocampus. (C) 2001 Elsevier Science B.V. All rights reserved.
\end{abstract}

Keywords: Hippocampus; Spatial cognition; Context recognition; Place cells; Cognitive map; DNMS; H.M.

\section{Introduction}

Hippocampal pyramidal cells show strong correlations to the location of the animal in space $[149,173]$. These correlations (termed the place field of the cell) show many important properties, including appearing immediately upon entry into a novel area [79,241], following synchronous rotations of external cues $[38,129,148]$, and continuing to show place fields in the absence of landmarks [129,152] and in the dark $[100,166]$. See [173] for review. These disparate properties can be explained by postulating a role of the hippocampus in associating external cues with an internal coordinate system (the cognitive map, [150]) $[86,108,173,177,196,225]$. Place fields also rearrange in response to non-spatial stimuli under certain conditions (see below), as well as in the face of cue-conflict, whether that be between external cues $[150,199,250]$, or

\footnotetext{
E-mail address: redish@ahc.umn.edu (A.D. Redish).

${ }^{1}$ Ideothetic cues are those that provide information about self-motion, such as vestibular and optic flow cues [122].
}

between external cues and internal idiothetic ${ }^{1}$ coordinate systems $[89,202]$. It is the contention of this paper that the sensitivity to non-spatial stimuli, as well as to cue-conflict, can also be explained by postulating a role of the hippocampus in associating external cues with internal representations, not of location on a cognitivemap, but rather of different maps. More generally, the hippocampus can be seen as associating external cues with an internal representation of context.

Looking at behavior, not all spatial tasks require an intact hippocampus (see [173] for review). This can be explained by postulating multiple navigation systems $[88,105,150,159,173]$, some of which require the hippocampus, some of which do not. Those that do include navigation tasks that require the recall of a context, or a context-switch [173]. Subtle task differences (such as the stability of certain cues or cue-combinations) can change whether a task requires a hippocampus or not. The hypothesis that the hippocampus is critical for allowing the bridging of contextual gaps leads directly into a role of the hippocampus in memory. 
The hippocampus has also been implicated in certain memory tasks (see below), in particular the delayednon-match-to-sample task (see below). As with navigation tasks, there are multiple memory systems $[78,120,121,140,158,159,213]$. It is the contention of this paper that the hippocampal involvement in memory tasks corresponds to the non-spatial correlates of the hippocampal pyramidal cells. In other words, those requiring a recall or reinstantiation of context.

I will first review the evidence for non-spatial correlates of hippocampal pyramidal cells, and then, I will argue for an important difference between spatial and non-spatial correlates. It is the contention of this paper that those differences are critical to the understanding of hippocampal function. Then I will review the role of the hippocampus in certain spatial navigation tasks, discussing some issues relating to hippocampal function within the navigation system. The conclusion will be that the primary role of the hippocampus lies in contextual-recall (termed reinstantiation of a context in [173]). This will lead directly into the discussion of memory and the role of the hippocampus in memory tasks, notably that of bridging contextual-gaps. Finally, I will lay out some open questions left by these hypotheses.

\section{Space}

\subsection{Non-spatial place cells}

Place cells were first reported by O'Keefe and Dostrovsky in 1971 [149]. Although O'Keefe and Nadel used a variety of experimental data to support their cognitive map hypothesis [150], it was unquestionably the existence of place cells that made their theory so influential. Those of us who have come into the field long after the acceptance of place cells can only imagine the surprise and disbelief that accompanied their initial discovery [14,142]. Although no one denies that under certain conditions, hippocampal pyramidal cells show spatial tuning curves (place fields), even today there are authors who argue that, dramatic though they may be, place fields are epiphenomena, a consequence of the spatial nature of experimental design $[46,71,142,246]$.

By this point, it is pretty much accepted that under certain conditions, hippocampal pyramidal cells show correlations to non-spatial aspects $[48,69,71,101,109$, $157,238,239,246,247,250]$ (see $[33,173]$ for reviews, but see [147] for an alternative viewpoint). These non-spatial aspects include when animals change task within an environment [101], in response to components of a task in which goals change $[48,69,157,247]$, even after salient events [202]. In addition, hippocampal cells show place field changes with changes in environments or the available constellation of cues $[17,90,93,129,148,181$, $219,223,250]$. Animals with learning deficits (whether by aging, NMDA-blockade, or cortical lesions) also show an instability of place fields across sessions, though not within the session itself $[8,11,87,127,189,190,220,221]$.

These experiments show conclusively that hippocampal cells are correlated to other aspects than merely the location of the animal. At the very least, the definition of place cell has to include the location of the animal within an environment, but place fields are also modulated by aspects of a task occurring within a single environment. Place fields are goal and task dependent. Must we then abandon the original cognitive map hypothesis made by O'Keefe and Nadel [150]?

\subsection{The multiple-map hypothesis}

The original hypothesis made by O'Keefe and Nadel in 1978 was that there was a cognitive map somewhere in the brain [150]. They made a distinction between navigation by routes and maps, in which routes were built to reach a specific goal, but maps were independent of goal, task, or behavior. The map was purely a function of the animal's representation of the environment [150]. The hippocampus was hypothesized to represent the position within an environment and goals, tasks, etc. were associated with it extrahippocampally. The change in place cells to these non-spatial aspects would seem to belie this hypothesis. As pointed out by Nadel [142], this does not doom the fundamental hypothesis that rodent navigation abilities require the presence of a cognitive map representation somewhere in the brain [150,224], or that the hippocampus is critical to its formation and use. Interestingly, extrahippocampal cells that show spatial tuning seem to be less sensitive to environment or other factors than hippocampal cells $[123,167,201,203]$, suggesting that they may form part of this extra-hippocampal map.

Is the cognitive map as hypothesized by Tolman [224] and O'Keefe and Nadel [150] really just a single intrinsic coordinate system represented in the hippocampus? I would argue that it is much more than this. Rather, I would argue that the reason O'Keefe and Nadel's book had such an influence on the field of hippocampal study was because it was about so much more than the hippocampus. For example, O'Keefe and Nadel made an explicit distinction between routes and guidances (which they together described as a taxon navigation system) and the cognitive map (which they described as a locale navigation system) [150]. They made the point that a taxon navigation system had navigation abilities that were different from a locale navigation system, thus predicting (correctly) that animals with hippocampal lesions would be able to perform some navigation tasks, but not others.

O'Keefe and Nadel also argued that in order for animals to show the abilities they do, there must be a 
mechanism for creating an allocentric ${ }^{2}$ spatial representation of the environment. So then, the question becomes: 'How does the rodent navigation system construct that allocentric representation?' A cell sensitive to a sufficient combination of egocentric cues will show allocentric tuning $[150,173,251]$. However, in order to accommodate all the known properties of hippocampal 'place' cells, one needs to include a variety of computational properties, including inputs from (presumably highly-processed) sensory representations, inputs from an intrinsic (extrahippocampal) coordinate system (updated by vestibular, proprioceptive, and motor-system efferent-copy), and intrinsic (intrahippocampal) autoassociator dynamics [173]. Taking this as a generalized computational model of hippocampus, the hippocampus is essentially representing the association between external (sensory) and internal (idiothetic) cues $[108,150,173,177,225]$.

This hypothesis puts the allocentric coordinate-system outside of the hippocampus, and suggests that it is not relearned from environment to environment. While it is unlikely to be genetically hard-wired, but rather likely to be learned during development, it is not relearned time and again by the adult animal. As noted above, cells in extra-hippocampal structures tend to be insensitive to the environmental changes that hippocampal cells are sensitive to [123,167,201,203]. This internal coordinate system has been termed the path-integration system by a number of authors [86,108,177,196,225,231].

Thus, while the hippocampus clearly does not play the role of a single cognitive map (in the strict sense), it may be thought of as a combination of maps (i.e. a combination of associations [mappings?] between external cues and an internal coordinate system). In the mid-1990s, two groups simultaneously and independently derived this multiple-map concept as a means of explaining the non-spatial place cell data [108, $173,177,196,225,231]$. We termed this property reference frames [173,177,225,231], suggesting that the navigation system switched reference frames between environments, tasks, etc.; McNaughton and colleagues termed this property charts $[108,196]$. The major difference between these theories lay in the reasons given for when animals would change reference frame or chart. Reference frames were a property of the entire navigation system, including a reference point represented by an extrahippocampal dead-reckoning (path-integration) system, a reference orientation represented by an extrahippocampal head-direction system, and representations that signaled changes in context (goals, tasks, etc.). In contrast, charts were a property of in-

\footnotetext{
${ }^{2}$ An allocentric representation is one that is independent of the location of the animal. Compare to an egocentric representation, in which spatial cue locations are represented relative to the animal.
}

trahippocampal dynamics. The two theories differed, in particular, in the internal or external nature of the idiothetic (dead-reckoning, path-integration) component: McNaughton and colleagues argued for an intrahippocampal idiothetic component [196], while we argued that it must be extrahippocampal [177]. Recent data has unequivocally supported the extrahippocampal hypothesis [5,98]. Alyan and McNaughton [5] tested rats in a food-retrieval task and showed that both normal animals and animals with obliterated hippocampi (lesioned with ibotenic acid) could return accurately in darkness. They also tested rats in a task in which animals had to dig through sand to return to their home position and found that both normal animals and animals with lesioned hippocampi could return home accurately. Maaswinkel et al. [98] also tested rats in a food-retrieval task, controlling for surface odor cues by rotating the environment while the rat waited at a central platform. They found that animals with lesioned hippocampi (again, by ibotenic acid) were significantly impaired relative to normals. However, their lesioned animals were still finding their way home better than would be expected by chance, implying an intact path-integration system ${ }^{3}$.

The essence of the multiple-map (reference frame, chart) hypothesis is that the non-spatial correlates reviewed above are a consequence of changes in the internal cognitive map being used by the rodent navigation system. This hypothesis suggests that changes in tasks, goals, etc. will require different maps. Imagine, for example, that you want to visit the Vietnam Veterans Memorial in Washington DC. If you are at the Air and Space Museum, you will need a walking map. If you are at NIH, in Bethesda, you will want a metro (DC subway) map. If you are in Frederick, an hour's drive north of DC, you will need a road map.

\subsection{Differences between spatial and non-spatial correlates}

As reviewed above, hippocampal cells show firing changes correlated with both spatial and non-spatial variables. A key question becomes whether the spatial and non-spatial correlations are equivalent or not. Memory theories suggest that they are equivalent $[4,33,46,246]$, while spatial theories suggest that nonspatial variables are second-order effects [177,196,225], or even deny their existence [147]. What I am proposing here is that spatial and non-spatial correlations are

\footnotetext{
${ }^{3}$ While Maaswinkel et al. interpret their data as supporting an intrahippocampal hypothesis, examination of their figures shows that animals with hippocampal lesions are clearly above chance levels, implying that the animals are still showing path-integration abilities. The hypothesis most consistent with their data is that the presence of a hippocampus helps correct for path-integration errors.
} 
both important, that they follow from similar processes, but that they show very different properties.

The theory that the hippocampus associates external cues with an internal cognitive map suggests an immediate difference between spatial and non-spatial parameters. With spatial aspects, the hippocampus associates external cues with where on the map the animal is, while with non-spatial aspects, the hippocampus associates external cues with which map the animal is on. This makes a prediction as to differences between how the hippocampus treats spatial and non-spatial cues. Spatial cues are treated continuously, while nonspatial cues will be treated as discrete elements or categorized.

This difference can be most easily understood by looking at the difference between traveling the length of a linear track. As the animal runs from one end to the other, the population of active cells changes slowly and continuously. Some cells show place fields at one end or the other, but some cells also show place fields in the middle of the track. These place fields in the middle of the track have tails on either side, so that the firing rate rises as the animal enters the field and then falls again as the animal leaves the field. Thus, while it is true that the cells with place fields active at one end of the track are an independently drawn sample relative to the cells with place fields at the other end of the track, the population of active cells changes continuously from one end to the other.

In contrast, imagine a population of cells which categorizes the track into two components (say left and right). Some cells would fire on the left half of the track but not on the right and some cells would fire on the right half but not the left. Some cells might also not differentiate the two halves, firing equivalently between the two. However, if the left and right halves of the track are treated as discrete elements, then all portions along the track would activate either the left-firing cells or the right-firing cells.

Interestingly, spatial cues are sometimes represented discretely: on a linear track, cells differentiate the two directions of travel $[67,101,109,174]$. However, when allowed to experience all directions without limitations (such as when foraging within an open environment), cells do not show any directional dependence at all $[101,128,130]$. We recently explored the moment of transition when animals turn around on linear tracks [174]. Rats were trained to run from a box to the end of a six foot track and to turn around, returning to the box. Animals received a food reward at the box only if they proceeded all the way to the end of the track. At locations on which animals had extensive experience (i.e. at the end of the track), there was a continuity of representation between the two directions, but at locations on which animals had not had extensive experience (i.e. when animals turned around early), the representation showed a discrete change between the two directions. Since most non-spatial variables are experienced discretely (for example, as samples in a delayed-non-match-to-sample-task, see below), nonspatial representations are categorized discretely.

The prediction is that continuously-experienced variables are represented continuously, while discretely-experienced variables are represented discretely. In practice, this distinction corresponds to spatial and non-spatial aspects: spatial aspects are experienced continuously, while non-spatial aspects are experienced discretely. The evidence at this point is that hippocampal cells clearly do show non-spatial correlations, but that those non-spatial correlations produce changes in place field activity. It is important to note that some cells may show place fields that are insensitive to nonspatial cues, even simultaneously with other cells that do differentiate non-spatial cues $[89,101,207,219]$. This has no impact on the hypothesis in question. Cells may be more or less sensitive to associations between specific aspects of the external cues and specific aspects of the internal coordinate systems $[86,173]$.

No one has as yet measured non-spatial cues along a continuous dimension. All non-spatial hippocampal correlates have been measured along categorized dimensions: specific odors $[48,246]$, whether a cue is black or white [17], whether the goal is to the left or right of a T-maze [54,247], whether a lever is to the left or to the right [71], whether two sequential cues match or not [69,157,193-195], which behavior is to be elicited [101], etc. In contrast, studies of spatial dimensions have shown conclusively that the representation changes continuously (e.g. [174], see [173] for review).

An interesting hypothesis put forward in [173] is that spatial and non-spatial cues enter the hippocampus through different pathways: the spatial through postrhinal cortex into medial entorhinal cortex and the nonspatial through perirhinal cortex into lateral entorhinal. Recently, evidence has begun to accumulate supporting this hypothesis. Lesions of perirhinal cortex do not disrupt place cell firing within an experimental session, but do disrupt stability across experimental sessions [127]. Cells in perirhinal cortex do not show robust spatial correlates, particularly when compared with medial entorhinal cortex [23]. To my knowledge, no one has as yet determined whether postrhinal cells show place fields or not.

\subsection{Multiple navigation systems}

There is a lot more to the brain than the hippocampus. Without the rest of the brain, the hippocampus does not function normally. Hippocampal slices certainly don't show place fields. While, obviously, no one expects behavioral correlates from hippocampal slices, many interpretations of hippocampal lesions ignore the 
implication of these other non-hippocampal navigation components.

For example, let us take the standard 'place navigation' task of the hidden-platform water maze [125]. The water maze consists of a large pool of water mixed with milk, chalk, or paint, so as to make the water opaque. Somewhere in the pool, there is a platform on which the rodent can stand and be out of the water. In the hidden-platform version, the platform is submerged just below the surface and is presumably invisible to the swimming rodent. In the visible-platform version, the platform sticks out above the surface.

Almost as soon as the water maze was first introduced, it was found that animals with hippocampal lesions could not find a hidden platform but could find a visible platform [126]. Animals with any number of deficits that impair hippocampus also had trouble with the hidden platform, but not with the visible-platform versions (see [173] for review). This was quickly taken as proof of O'Keefe and Nadel's cognitive map hypothesis [126]. But, since those initial studies, it has been shown that animals with a variety of hippocampal impairments could, in fact learn the hidden-platform water maze if they were given appropriate training $[41,49,232-235]$

The issue, of course, is that the water maze is not solved by a hippocampus in isolation, it is solved by a navigational system involving many structures beyond the hippocampus. These non-hippocampal structures may be able to solve the water maze under specific training paradigms. In particular, as predicted by O'Keefe and Nadel [150], non-hippocampal navigation systems require immediate sensory cues off of which they can trigger the response (for example, hippocampal animals can beacon to a visible cue [49]). When immediate cues are not available, non-hippocampal navigation systems can learn to trigger off more complex cues if given sufficient training and if the complex cues are sufficiently different (for example, if they are first overtrained with a visible platform [234]).

Hippocampally-impaired animals can find the hidden platform if they are always started from the same location $[49,235]$, if a cue is available toward which they can swim [49], if a cue is available from which they can generate a heading vector [162], or if they are overtrained first with a visible platform [234]. One of the best examples of a specific training paradigm that allows animals to show place learning with hippocampal lesions is training the animal with a shrinking platform [41]. Animals with hippocampal lesions were first trained with a large platform that filled almost the entire maze. Once the animals could reach the platform reliably, it was shrunk trial by trial until it was the same size as a typical hidden platform used in the water maze. Looking at the entire navigation system, one can see that the taxon navigation component (a slowly- learned association between cues-seen and direction-toswim) could learn this task, but would require a different computational paradigm than a locale navigation component (a quickly-learned association between external cues and an internal coordinate system from which the direction-to-swim can be derived) [177]. The proof that animals with intact and lesioned hippocampi were using different strategies was that, on the trials in which the platform had just been shrunk, hippocampallesioned animals were faster to find the platform than normal animals [41]. As reported by Day et al. [41], hippocampal-lesioned animals swam straight through the area which on the previous trial had contained part of the platform (and on the trial in question did not), while hippocampal-intact animals spent time searching at the boundary where the platform had been. This can be explained by the multiple-navigation-system hypothesis by arguing that hippocampal-lesioned animals only knew to swim in a direction, they did not know the actual location of the platform, while, animals with intact hippocampi recognized that the platform had been shrunk and searched the original platform boundary before lighting on the new, smaller platform.

\subsection{The role of the hippocampus}

The hypothesis then is that the role of the hippocampus in navigation is to associate the internal and external coordinate systems $[108,173,177,196,225]$, and to accommodate cue-conflict situations [171,173,177,225]. The hippocampus may also provide error-correction facilities for the internal coordinate system. Dead-reckoning systems produce intrinsic errors which accumulate with distance traveled [59]. External cues that have been previously associated with the internal coordinate system can correct for these accumulating errors $[177,196]$. Hippocampal-lesioned animals are impaired at correcting those accumulating errors [98].

It is interesting to differentiate this cognitive map theory in which there is an intrinsic, allocentric coordinate system and external cues are associated with that $[108,173,177,196,225]$ from the original O'Keefe and Nadel theory in which the allocentric coordinate system is constructed from the egocentric representations $[22,146,150,171,200,251]$. In the original theories, the allocentric map is constructed from cells which are sensitive to multiple egocentric cues [22,146,171, 200,251]. Cells sensitive to a sufficient number of egocentric cues will show place fields which are compact, rotate when the full set of cues rotate, and are disrupted when the relationships between the cues change $[173,200,251]$. However, these theories cannot account for place cell activity in the dark [100,166,225], nor can they account for the sensitivity of place cells to starting location of the animal [176,200]. The association theory, in contrast, suggests that there is an inter- 
nal, intrinsic (extrahippocampal) coordinate-system that provides additional input to the hippocampus and that the hippocampus learns to associate the external cues with that internal coordinate system [108,173, $177,196,225]$.

The multiple-map extension of this is that the hippocampus is not just involved in aligning the internal coordinate system (dead-reckoning, path-integration system) with the external cues (the local-view), but in resetting the entire internal contextual representation [173]. In effect, the multiple-map hypothesis says that it is not sufficient to know where you are within an environment, you also have to know what environment you are in, what you are doing there. You have to know the complete context. The role of the hippocampus is to reinstantiate the context when there is a mismatch between the internal and external representations.

\section{Memory}

\subsection{H.M.}

At age 27, in 1953, the patient known to neuroscience as H.M. received surgery removing large portions of his temporal lobes as a treatment for intractable epilepsy [198]. When H.M. recovered from his surgery, his doctors discovered a profound anterograde and retrograde amnesia [198]. Further tests noted that only some aspects of memory were impaired, particularly those generally described as declarative (such as remembering incidents, numbers, or lists of unrelated words $[35,116,198])$; other abilities were still intact, particularly those generally described as procedural (such as mirror-reading [35], mirror-writing [116], and rotarypursuit [36]).

Even in 1957, the hippocampus was the focus of research in the temporal lobe. Since even before the studies of Ramón y Cajal and of Schaffer in the 1880s [168], it has been identified as special. So, although the surgeon's estimates of excised brain clearly indicated extensive damage beyond the hippocampus, it was the hippocampus that Scoville and Milner concentrated on in their case-study report of H.M. [198]. In the subsequent years, declarative memory experiments and models would concentrate on the role of the hippocampus $[33,103,104,180,211,212,255]$.

However, recent MRI scans of H.M.'s lesion have shown that not only is he missing much more of his temporal lobe than previously thought, but that the caudal half of his hippocampus is still intact (though its functionality cannot be determined) [37]. And animal studies attempting to study recent declarative memory are inconsistent in their conclusions as to whether the hippocampus is involved in declarative memory or not
$[4,26,27,32,33,45,47,70,113,119,133,135,137,142,147,173$, 253,257,258]. Most of these animal studies involve the delayed-non-match-to-sample or DNMS task [4,26,27, $32,45,70,113,119,133,135,137,253,257,258]$. As with the water maze for spatial cognition, the DNMS task is a complex task that can be solved in a number of ways. Depending on specifics of training paradigms as well as individual differences between animals, animals may use different systems to solve this task, complicating any measure of hippocampal involvement.

\subsection{The delayed-non-match-to-sample task}

So much has been made of this task and its relation to hippocampus that some space must be taken to examine it. The DNMS task consists of two stages separated by a delay: first the animal is presented by one or two objects (samples), then the delay is imposed, finally the animal is faced with two objects, one of which is from the previous stage and the other of which is new. The animal is rewarded for selecting the new object. The delay can be imposed in a variety of ways, a rat may be required to return to a home base and wait there; a monkey can have a screen lowered between it and the objects; or the animal can be carried back to another cage to wait through the delay. I will argue that both the method by which the delay is imposed and properties of the samples themselves are important.

The history of hippocampus and DNMS traces back to at least the late 1970s, with Mishkin's work attempting to replicate the dramatic deficits seen in H.M. $[119,135]$. These early studies found that while lesions of hippocampus or amygdala alone were unable to produce impairments in DNMS, combined hippocampus and amygdala lesions were devastating [119, 133,135]. These studies, however, used aspiration lesions which meant that the cortex ventromedial to the hippocampus and amygdala suffered collateral damage [133]. Lesions restricted to these ventromedial areas (the rhinal cortex, including both entorhinal and perirhinal areas) had as much effect as the combined hippocampus + amygdala lesions previously seen $[113,133$, $136,257,258]$.

This would seem to suggest that the key to the DNMS task lay in extrahippocampal structures, however, a variation in the lesion re-energized DNMS as a hippocampal-dependent task. Patient R.B. had an ischemic incident during complications stemming from a coronary artery bypass operation [256]. Following this incident, R.B. developed profound anterograde amnesia much like that of H.M. In particular, R.B. showed severe deficits in DNMS-like tasks [256]. After his death, the only damage observable histologically was to the CA1 field of the hippocampus [180,256]. This lab has since reported three additional patients with similar 
deficits, all with similar histologically-observable damage [180]. DNMS is also impaired by ischemic lesions of rats [248] and monkeys [9]. But again, it was shown that even this ischemic lesion produces extrahippocampal damage, which may not be observable histologically using standard methods. Mumby et al. [132] showed that hippocampal ablation (by aspiration and electrolysis) protected against the ischemic effect on DNMS, animals that first received ischemia followed by ablation were severely impaired at DNMS; but animals that first received ablation and then ischemia were not. This suggests that somehow the effect of ischemia is to produce transient hippocampal activity which negatively affects downstream structures [132].

This would seem to have doomed the hypothesis that the hippocampus played the critical role in DNMS. However, it had already been known for many years that both fornix lesions (which partially deafferent the hippocampus) and hippocampal lesions produce devastating deficits in spontaneous alternation [42,44], which can be seen as a sort of continuous (spatial) non-matchto-sample of position. Spontaneous alternation is a task on a T-maze in which animals are rewarded for entering the arm not entered on the previous trial, in other words for alternating goal arms [42]. Unlike the DNMS tasks used with monkeys and humans, the two samples in spontaneous alternation are spatial: in order to sample them, the animal must physically move itself into one or the other $[1,144,150,259]$.

When tested in a continuous spatial alternation task (a T-maze with returns, allowing the animal to run in a Figure-8 pattern), hippocampal pyramidal cells do differentiate the two components along the shared component of the path [247]. On other alternation tasks (such as back-and-forth along a linear track, i.e. alternating directions), cells differentiate the two directions [67,101,109,174].

On another spatial non-match task, the eight-arm radial-maze, in which animals are only rewarded for entering an arm not entered before [155], hippocampal cells differentiate the arms of the radial maze, as well as directions (in vs. out) on each arm $[109,154]$. Importantly, while hippocampal cells differentiate arms and directions on all versions of the radial maze, hippocampal lesions only affect spatial, not visually-cued versions of the radial-maze $[10,85]$. This raises a key issue in understanding the hippocampal involvement of DNMS and other memory tasks: not all cues are represented equally.

\subsection{Not all cues are equal}

We have seen this before. If a visible cue is available at the end of each arm of the radial maze, animals with hippocampal lesions continue to be able to differentiate the arms $[10,85]$. If a visible cue is available above the platform in the water maze, or if the platform itself is visible above the water, then animals with hippocampal lesions can continue to find the platform $[49,126]$. Dudchenko et al. [45] directly compared odor recognition memory and spatial recognition memory. They found that hippocampally-lesioned animals were as good as normals on odor recognition, even when required to remember 11 odors. In contrast, hippocampal animals performed at chance when forced to remember spatial locations.

An analogous debate has raged within the configural learning literature. Configural learning is the ability to recognize $\mathrm{A}+\mathrm{B}$ as different from $\mathrm{A}$ and different from B [191,216]. Computationally, it is often termed the XOR or parity problem: given two binary inputs and one binary output, the output value should be equal to 0 if both inputs are 0 or both inputs are 1 ; and 1 if one input is 0 and the other is 1 . This problem is not solvable by a linear network [118] but is solvable by a nonlinear network [77]. Some authors have proposed that the hippocampus is critical for configural learning $[191,216]$, but the rest of the brain is certainly not a linear processor and thus should be able to solve the XOR problem. Hippocampal-lesioned animals can solve some configural problems, but not others. When the two cues are temporally and spatially compact, neither hippocampal nor fornix lesions impair configural learning $[40,58,236,237]$. When the cues are environmental, hippocampal or fornix lesions produce configural learning impairments [2,3].

Hippocampal lesions affect recognition-memory when the choices are contexts that must be physically entered. As noted above, hippocampal lesions affect spatial non-match tasks such as spatial alternation $[42,44]$ and the radial-maze [153]. Similarly, hippocampal lesions affect the radial and water mazes only when no direct cues are available. Cassaday and Rawlins $[26,27]$ tested rats in a delayed-match-to-sample (DMS) task of choices between two goal boxes. Neither hippocampal nor fornix lesions affected DMS success except when the animals had to physically enter the goal. Control experiments showed that the problems animals had with enterable choices did not have to do with interference, complexity, or simplicity [26]. Similarly, early studies by Gaffan found that fornix lesions disrupted this sort of recognition memory in rats [56], but not in monkeys [57]. However, while the rats were tested with a T-maze spatial recognition task [56], the monkeys were tested with a visual choice recognition task while sitting in front of a screen [57].

\subsection{Multiple memory systems}

As with the water maze reviewed in the discussion of space, above, memory tasks can be solved in a number of ways. Distinctions can be drawn between 
- active memory (in which a representation of the stimulus is held in neural activity) [55,64,252],

- filtering mechanisms (in which individual neurons respond differently to novel and to familiar objects $[114,115]$, probably an implementation of perceptual priming [240]), and

- content-addressable memories (memory stored in interneuronal connections, presumably through LTPlike mechanisms) $[75,83,110,156,171,184]$.

Each of these processes have advantages and disadvantages. Active memory is sensitive to distractors, but there is a clear error-detection condition - if the memory is forgotten, the system can recognize that it has been forgotten. Filtering mechanisms are not all-ornone propositions, but they cannot combine cues separated across space or time. Finally, content-addressable memory systems are regenerative (the memory is regenerated or completed from cues) and thus are not sensitive to distractors, but they are an all-or-none proposition - if the wrong memory is retrieved, that fact (that the retrieval failed) can be impossible to recognize.

These processes involve different anatomical structures. Active memory mechanisms seem to access frontal cortical areas $[55,64,97]$, or at least interactions between frontal and other cortical areas [43,114]. Filtering mechanisms seem to occur in sensory systems (such as inferotemporal cortex [114,115]). Content-addressable memory systems are usually attributed to the 'hippocampal formation' [33,156,184]. The question remains, however, whether these mechanisms are truly hippocampal or whether they preferentially involve the nearby cortical structures.

The argument being made here is that when the task requires a contextual bridge and cues associated across space and time (i.e. a context), the system requires the hippocampus [173].

It is important to distinguish this theory from the purely spatial theory [150] and from purely relationalmemory theories $[33,191,216]$. The purely-spatial theory does not recognize the necessity of including context beyond space, although recent modifications of it do [145], and the purely relational-memory theories suggest that all cue-pairings are equivalent. Other authors have suggested that the hippocampus is critical in bridging temporal gaps: Rawlins [170] suggested that the hippocampus forms a high-capacity storage with a slow decay rate. Wallenstein et al. [230] suggested that the hippocampus associates discontiguous events. As pointed out in the commentary on Rawlins' paper [34], rats are not impaired on identically timed, but differentially cued tasks (thus implying that not all cues are equal). Jarrard [84] noted that in situations where the discontiguity does not include distractors, hippocampal animals are able to perform many delayed non-match tasks. Content-addressable memories are less suscepti- ble to interference than the other memory systems, and mechanisms by which content-addressable memories can be protected against interference have been extensively studied [73,74].

As with the spatial aspects, the role of the hippocampus in memory seems to be critically involved in bridging contextual gaps. There are two keys here: cues that relate to the overall environment or context and a discontiguity, whether it be temporal or spatial. Distractors occurring within the discontiguity will make the task more likely to be hippocampally susceptible. If one or the other of these conditions are not met, another memory system may be able to solve the problem, even with an impaired or missing hippocampus.

\section{Discussion}

In the spatial navigation domain, the hippocampus re-localizes an animal within a context; in the memory domain, the hippocampus bridges contextual gaps. The hippocampal context-reinstantiation theory derived originally from examining the rodent spatial navigation system [173], but reaches back to both spatial [150] and non-spatial theories $[56,80,170]$.

\subsection{What's a context?}

One of the big questions left open within the "contextual recognition' theory is the difference between cue and context. From the effect of hippocampal lesions, it is clear that the question of context is a complex one. For example, rats with hippocampal lesions can solve both simple and complex object-related DNMS tasks but they cannot differentiate long goal-boxes which they need to physically enter [26], see above.

Additional indications beyond the lesion data are available as to what should be considered different contexts: the multiple-map hypothesis suggests that when the topology of place fields changes, then we are observing a context-switch. This happens when animals change environments [93,223], when animals reverse direction on repeated paths [101,109], when animals change task within an environment [101], in response to components of a task in which goals change [48,157,247], with changes in salient cues [17], and in response to incompatible cue manipulations [89, 175,202,204,219].

Some learning deficits cause an instability of place fields across sessions, but not within a session $[11,127,189,190]$. This instability can be seen as an error in contextual-retrieval. In other words, once the system has retrieved a context, the topology of fields is generally stable, but during contextual retrieval the topology is unstable. Animals that have not successfully associ- 
ated the external and internal cues may recall the wrong context when forced to bridge a contextual gap $[173,179,196]$.

An open question, however, is "What constitutes the context?" The answer may well be that it depends on the specifics of the task, of the procedure, and perhaps even of the animal itself. Another important, not yet answered question is: "Is there a difference between rats, monkeys, and humans as to what defines the context?" Monkey hippocampal cells seem to show spatial view fields $[60,186,187]$ in contrast to the place fields seen in rats ([149] see [173] for review). Whether this difference corresponds to a difference in perception of context remains to be seen.

\subsection{Slipping out of context}

In a recent study, Zola et al. [253] performed a meta-analysis of their previous studies, including ischemic, radio-frequency, and ibotenic-acid lesions. These monkeys were all tested at 8 and $15 \mathrm{~s}$, and 1,10 , and 40 min delays. The performance of all three of these groups show the same pattern of delay-dependent impairment. In each group, small, non-significant deficits appear at the shorter delays, with the deficits reaching significance at the longer delays. By pooling across the groups, a population could be generated with 18 lesioned animals. These animals showed small but significant deficits even in the $15 \mathrm{~s}$ condition [253].

This theory, then, explains the delay-dependent deficits seen by Zola et al. [253] as reflecting a loss of contextual-memory. If we ask how an animal can solve the DNMS task, we see that both active memory and content-addressable-memory mechanisms would be helpful. However, use of the active memory mechanism requires maintenance of the memory across the delay. If an animal has both mechanisms available and gets distracted, the content-addressable-memory mechanism can reinstantiate the context. The theory suggests that animals with hippocampal lesions are impaired at that reinstantiation. In other words, if an animal 'slips out of context', it can not get back. In a sense, the hippocampal lesion uncovers a delay-dependent deficit.

A good example of this is in one of the original studies used in the meta-analysis by Zola et al. [4]. In this study, monkeys were given radio-frequency hippocampal lesions, and tested at the delays listed above. The monkeys only showed impairments at 10 and at 40 min delays [4]. However, the monkeys were returned to their home cages for the 10 and $40 \mathrm{~min}$ delays. In doing so, the experimenters imposed a context-switch, which might have impacted hippocampallylesioned animals more than normals $[141,173]$. When tested in a continuous DNMS task, monkeys with hippocampal lesions were as capable as normals even out to delays of $40 \mathrm{~min}$ [137].
Amnestic humans show these same sorts of contextswitch deficits [97,210]. For example, they can hold normal conversations, but cannot remember facts across conversations $[33,117,197]$. In the initial analysis of their temporal-lobe-lesioned patients (including H.M. and other patients), Scoville and Milner [198] noted that these patients could remember a three-figure number, but they forgot it the instant attention was diverted. H.M., in particular, could remember a number for $15 \mathrm{~min}$ using constant rehearsal (i.e. active memory), but as soon as the examiner changed the subject, he forgot that he had even been given a number to remember [116].

\subsection{Space and memory}

One intriguing possibility is that there are two pathways by which information can leave the hippocampus: through the fornix, which carries efferent output from hippocampus and subiculum to subcortical structures such as the nucleus accumbens, the anterior thalamus, the septal bodies, and the mammillary nuclei [245], and through a separate connection carrying efferent output from CA1 and subiculum to the deep entorhinal cortex $[31,242]$, from which it is then redistributed to nearly the entire neocortical mantle $[95,228,243]$. If the accumbens plays a role in action selection [68,124,163], and the entorhinal cortex plays a role in memory formation $[28,138,214,218,244]$, then it is possible that the same internal information is redistributed in different ways across the two pathways. Navigation models extending to anatomical structures beyond hippocampus have tended to include models of accumbens as the "next stage downstream' $[19,22,53,177]$, while memory models have tended to emphasize the entorhinal-hippocampusentorhinal loop [4,24,33].

Recently, Clark et al. [32] examined rats with fornix or hippocampal lesions. They tested the animals on an unrewarded DNMS task, the visual-paired-comparison (VPC) task. In this task, the rats were allowed to explore two identical objects (small glass, plastic, or ceramic objects placed within a testing environment). A delay was then imposed and the animals were exposed to a third copy of the identical object along with a novel object in the same testing environment. No reward was given, but normal animals naturally explore the novel object [51]. They found that hippocampal lesions did not affect exploration of the novel object after $10 \mathrm{~s}$ and $1 \mathrm{~min}$ delays, but did after $10 \mathrm{~min}, 1 \mathrm{~h}$, or $24 \mathrm{~h}$ delays. (Animals were returned to a home cage for the longer delays, but not for the shorter delays. Whether this affected the data as was suggested earlier in relation to the monkey data $[4,141,173]$ is not clear since the rats were returned to a holding cage during the shorter delays.) What was interesting in the Clark et al. [32] data was that fornix lesions did not affect the 
exploration, that is, animals with fornix lesions still preferred to explore the novel object, even after a $24 \mathrm{~h}$ delay. The fornix lesions, however, were enough to obliterate spontaneous alternation - animals with fornix lesions were at chance in spontaneous alternation [32].

\subsection{Conclusion}

Ever since the dramatic twin experiments of H.M.'s surgery and of place cells, the role of the hippocampus has been a whirlpool of theory, experiment, and debate. While many open questions still remain, tremendous progress has been made. The convergence of theory and experiment at a computational level is remarkable. Non-spatial hippocampal correlates can be explained. Place cell recordings are examining detailed quantitative second-order properties of the tuning curves, including both spatial $[39,112,151,174,208]$ (to list only a few) and non-spatial [11,94,247], and these properties are being modeled at a quantitative level [16,172, $196,205]$. Detailed explanations of hippocampal roles in both spatial and non-spatial tasks are available $[72,173,196,225]$. The theories themselves have converged on a basic hippocampal functionality in which hippocampal cellular activity follows from an interaction of external cue representations, internal dead-reckoning (path-integration) representations, and contextual representations, all processed through an intrinsic autoassociator system within the hippocampus [76,108,171,173,177,185].

Most memory researchers accept the hypothesis that there are multiple memory systems in the brain $[33,35,120,140,211]$. Similarly, most navigation researchers accept the hypothesis that there are multiple navigation systems in the brain $[150,173]$. Interestingly, the division made in memory (into declarative and procedural systems) $[33,35,120,211]$ parallels very closely the division made in navigation (into locale and taxon systems) $[150,173,226]$. In memory, declarative strategies are learned quickly, allow extensive flexibility, and involve the hippocampus $[33,104,120]$, while procedural strategies are learned slowly, are inflexible, and involve the basal ganglia $[91,120,192]$. In navigation, locale navigation is learned quickly, allows extensive flexibility, and involves the hippocampus [126,150,173], while taxon navigation is learned slowly, is inflexible, and involves the caudate nucleus (part of the basal ganglia) $[105,160,173]$.

There are, of course, still lots of open questions. The role of the hippocampus in retrograde amnesia is still under debate $[131,143,180]$ (see Appendix A). As are the specifics of the hippocampal place field parameters (such as the causes for directionality [21,101, $174,200,225]$ and phase precession $[16,151,188,208,227])$ and the role of the hippocampus in non-spatial tasks (such as contextual conditioning $[52,63,65,66,82]$ ). The twin experiments of H.M.'s surgery and place cells drove two major theories that have driven experiments too numerous to cite here. These experiments have engendered new theories. These theories will engender new experiments, which will, I'm sure, force a re-analysis of those theories in turn.

\section{Acknowledgements}

The author would like to thank J. Gewirtz, J. Nagode, E.S. Rosenzweig, and three anonymous reviewers for helpful comments on an early draft of this paper.

\section{Appendix A. Memory Replay and Consolidation}

Many readers may be wondering at this point how the reinstantiation role assigned to the hippocampus relates to the memory consolidation hypothesis $[33,104,182,198,211]$. It is, in fact, agnostic as to whether the hippocampus plays a role in consolidation.

The key to consolidation is the idea that memories remain fragile for a limited time after formation but then become less fragile with time [33,104, 106,182,198,211]. The key experiment is evidence that manipulations affect more recent memories more than older memories (i.e. they produce graded retrograde amnesia) [33,182,211]. Because H.M. showed what appeared to be graded retrograde amnesia [117,197], and because H.M. was thought to have a hippocampal lesion ([198], but see [37]), it was thought that hippocampal lesions produced graded retrograde amnesia $[33,143,180,211]$. The general hypothesis has been that hippocampus stores memories quickly and then replays them for permanent storage in cortex [24,103,104,215].

\section{A.1. Hippocampal representational replay}

There is now strong evidence that hippocampal representations active during awake states are replayed during subsequent sleep states [94,139,161,206,241]. This has been taken as evidence for a hippocampal role in consolidation. However, one needs to be cautious about the implications of this data. A replay of recent memories in hippocampus would certainly be useful for training downstream structures [24,102,215], but, as yet, there is no direct evidence that replay of hippocampal representations have any influence on neocortical representations.

There is indirect evidence that this replay of hippocampal representations may influence deep entorhinal activity. The hippocampus shows two differen- 
tiable states during which the intrahippocampal EEG shows very different characteristics [24,150,229]. One state, called theta, shows a profound $7-10 \mathrm{~Hz}$ rhythm $[150,229]$ with a higher $40 \mathrm{~Hz}$ rhythm (called gamma) riding above it [18] and occurs during movement and other attentive behaviors [229]. During theta, cellular activity tends to be smooth; a relatively constant proportion of hippocampal pyramidal cells fire spikes, with each cell firing on the order of a second or two $[94,150,169]$. The other state, called LIA (large-amplitude irregular activity) shows a noisier EEG punctuated by occasional $100 \mathrm{~ms}$ sharp-waves with a $200 \mathrm{~Hz}$ rhythm riding on them $[25,150,229,249]$. Cellular activity in LIA is usually quiet, with strong bursts of activity during the sharp-waves $[25,94,150,169]$. Place fields are only seen during theta states; during LIA states, cells fire during sharp-waves, independent of the location of the animal $[94,150]$. The theories that predicted replay of hippocampal states during sleep suggest that information is written into hippocampus during theta and read out during LIA [24,102,215]. While superficial entorhinal cortex (input to hippocampus) shows cellular activity correlated to theta [29,31], deep entorhinal cortex (output from hippocampus) shows cellular activity related to LIA and sharp-waves [30,31].

There is also some evidence for replay of representations during REM sleep as well $[96,161,164]$. Intriguingly, replay of familiar and novel memories occur at different phases of the theta rhythm: novel memories are replayed at the peak of REM-theta, while familiar memories are replayed at the trough [164]. As pointed out by Poe et al. [164], when taken with data showing that LTP is stronger at the peak than at the trough of theta [81], this may be a mechanism for strengthening new memories and erasing old ones in hippocampus.

\section{A.2. Implications}

However, again, one must be cautious with this interpretation. The hippocampus is now known to be required for certain types of very long-term memories $[92,131,143]$. As noted in [173] and by Sutherland and McNaughton in [215], there are two time-courses for consolidation that draw from very different literatures: short-term consolidation and long-term consolidation. Evidence for short-term consolidation (on the order of seconds to hours to days) consists of data showing that manipulations such as electroconvulsive shock [106] and NMDA-blockers [209] given shortly after the experience can impair memory storage. These manipulations probably disrupt LTP or other cellular mechanisms. Evidence for long-term consolidation (on the order of weeks to months to years) consists of data showing that after lesions, older memories are better remembered than recent memories [143,182,211,222].
Much of the early lesion data suggestive of a role of hippocampus in long-term consolidation included damage to nearby cortical structures [134,180,198,254]. If we ask what computational and anatomical aspects a putative temporary storage buffer requires, we find that it must be able to store memories quickly and replay them and that it must be connected to many other structures. Although LTP is well-known within the hippocampus $[15,20,99,107]$, it exists in the cortex as well $[12,13,183]$. Though no study has examined replay in entorhinal cortex, one study has examined replay in parietal cortex and found it present there [165]. The extrinsic connections of hippocampus are, in fact, extremely limited [6,242], while the nearby extrahippocampal structures are much more extensively connected with the rest of the brain [23,217,228,243].

It is also not necessarily true that the information is stored similarly in hippocampus and in the downstream structures replayed into. For example, the information represented in the hippocampal pyramidal cells during theta really seems to be the position of the animal within a context (see above). However, the information replayed during LIA states appears to be the recently traveled routes $[139,178,206]$. One possibility is that what is stored in the cortical memory is a habit-based route memory [178]. Intriguingly, this may be the normal transfer of memory from quickly-learned to slowlylearned mechanisms. My favorite example of this is driving to a new job-at first, one must pay attention to which turns to make and which streets to take, but after sufficient experience, the journey begins to become automatic, until, eventually, if you are not careful, you will end up at work even if you intended to go somewhere else.

All we really know at this point is that hippocampal representations are replayed during sleep states. We do not actually know that those representations influence subsequent cortical representations. We do know, however, that hippocampal replay seems to be unrelated to learning: old animals (who tend to have deficient LTP) have (as best as can be determined) normal representational replay [61,62]; animals injected with a dose of CPP sufficient to block LTP have normal representational replay [50].

\section{A.3. Reinstantiation and replay - the dual-role hippocampus?}

As mentioned above, the reinstantiation theory is agnostic as to the role of the replay of hippocampal representations. It can afford to be so because reinstantiation (recall) is computationally compatible with replay $[173,178]$. Theories of the computational function of hippocampus suggest that it has winner-take-all properties within an attractor network $[111,173,196]$ : excitatory connections between pyramidal cells with 
overlapping place fields [241] and inhibitory feedback connections within the CA3 system force it to represent a single location $[173,196]$. We call this a coherent representation [175].

The two roles can be implemented by a single attractor network with different boundary conditions $[173,178]$. If there are externally supplied inputs, then the network will find the coherent internal representation that is most consistent with those inputs $[173,178,196,225]$. But if there are no externally supplied inputs, then the network will still find a coherent representation of some random location. Slight variations in the internal connections or in the cells themselves will increase the likelihood of returning to a previously experienced representation $[178,205]$. Sequences can be stored within this network by weak asymmetries in the connection strengths [7,173,178]. With external input, the asymmetries will not be strong enough to affect the recall mechanism [173,178]. Presumably, during awake states, representations of external cues reach the hippocampus, but during sleep states they do not.

In other words, the contextual-reinstantiation theory is agnostic as to the presence of hippocampal replay because it is completely compatible with it. The mechanisms that would enable hippocampal replay do not interfere with the mechanisms that enable contextual reinstantiation.

\section{References}

[1] Altman J, Brunner RL, Bayer SA. The hippocampus and behavioral maturation. Behav Biol 1973;8:557-96.

[2] Alvarado MC, Rudy JW. Rats with damage to the hippocampal-formation are impaired on the transverse-patterning problem but not on elemental discriminations. Behav Neurosci 1995;109:204-11.

[3] Alvarado MC, Rudy JW. A comparison of kainic acid plus colchicine and ibotenic acid-induced hippocampal formation damage on four configural tasks in rats. Behav Neurosci 1995; 109:1052-62.

[4] Alvarez P, Squire LR. Memory consolidation and the medial temporal lobe: a simple network model. Proc Natl Acad Sci USA 1994;91:7041-5.

[5] Alyan S, McNaughton BL. Hippocampectomized rats are capable of homing by path integration. Behav Neurosci 1999;113:19-31.

[6] Amaral DG. Emerging principles of intrinsic hippocampal organization. Curr Opin Neurobiol 1993;3:225-9.

[7] August DA, Levy WB. Temporal sequence compression by an integrate-and-fire model of hippocampal area CA3. J Comput Neurosci 1999;6:71-90.

[8] Austin KB, Fortin WF, Shapiro ML. Place fields are altered by NMDA antagonist MK-801 during spatial learning. Soc Neurosci Abstr 1990;16:263.

[9] Bachevalier J, Mishkin M. Mnemonic and neuropathological effects of occluding the posterior cerebral artery in Macaca mulatta. Neuropsychologia 1989;27:83-105.
[10] Barnes CA. Spatial learning and memory processes: the search for their neurobiological mechanisms in the rat. Trends Neurosci 1988;11:163-9.

[11] Barnes CA, Suster MS, Shen J, McNaughton BL. Multistability of cognitive maps in the hippocampus of old rats. Nature 1997;388:272-5.

[12] Bear MF. A synaptic basis for memory storage in the cerebral cortex. Proc Natl Acad Sci USA 1996;93:13453-9.

[13] Bear MF, Kirkwood A. Neocortical long-term potentiation. Curr Opin Neurobiol 1993;3:197-202.

[14] Best PJ, White AM. Placing hippocampal single-unit studies in a historical context. Hippocampus 1999;9:346-51.

[15] Bliss TVP, Lynch MA. Long-term potentiation of synaptic transmission in the hippocampus: properties and mechanisms. In: Landfield PW, Deadwyler SA, editors. Long-Term Potentiation: From Biophysics to Behavior. New York: Liss, 1988:372.

[16] Bose A, Booth V, Recce M. A temporal mechanism for generating the phase precession of hippocampal place cells. J Comput Neurosci 2000;9:5-30.

[17] Bostock E, Muller RU, Kubie JL. Experience-dependent modifications of hippocampal place cell firing. Hippocampus 1991;1:193-206.

[18] Bragin A, Jando G, Nadasdy Z, Hetke J, Wise K, Buzsáki G. Gamma $(40-100 \mathrm{~Hz})$ oscillation in the hippocampus of the behaving rat. J Neurosci 1995;15:47-60.

[19] Brown MA, Sharp PE. Simulation of spatial learning in the Morris water maze by a neural network model of the hippocampal formation and nucleus accumbens. Hippocampus 1995;5:171-88.

[20] Brown TH, Zador AM, Mainen ZF, Clairborne BJ. Hebbian modifications in hippocampal neurons. In: Boudry M, Davis JL, editors. Long-Term Potentiation: A Debate of Current Issues. Cambridge, MA, USA: MIT Press, 1991:357-89.

[21] Brunel N, Trullier O. Plasticity of directional place fields in a model of rodent CA3. Hippocampus 1998;8:651-65.

[22] Burgess N, Recce M, O'Keefe J. A model of hippocampal function. Neural Networks 1994;7:1065-81.

[23] Burwell RD, Amaral DG. Perirhinal and postrhinal cortices of the rat: interconnectivity and connections with the entorhinal cortex. J Comp Neurol 1998;391:293-321.

[24] Buzsáki G. Two-stage model of memory trace formation: a role for 'noisy' brain states. Neuroscience 1989;31:551-70.

[25] Buzsáki G, Leung LW, Vanderwolf $\mathrm{CH}$. Cellular bases of hippocampal EEG in the behaving rat. Brain Res 1983;287:139-71.

[26] Cassaday HJ, Rawlins JNP. Fornix-fimbria section and working memory deficits in rats: stimulus complexity and stimulus size. Behav Neurosci 1995;109:594-606.

[27] Cassaday HJ, Rawlins JNP. The hippocampus, objects, and their contexts. Behav Neurosci 1997;111:1228-44.

[28] Cho YH, Berracochea D, Jaffard R. Extended temporal gradient for the retrograde and anterograde amnesia produced by ibotenate entorhinal cortex lesions in mice. $\mathbf{J}$ Neurosci 1993;13:1759-66.

[29] Chrobak JJ, Buzáki G. Gamma oscillations in the entorhinal cortex of the freely behaving rat. J Neurosci 1998;18:388-98.

[30] Chrobak JJ, Buzsáki G. High-frequency oscillations in the output networks of the hippocampal-entorhinal axis of the freely behaving rat. J Neurosci 1996;16:3056-66.

[31] Chrobak JJ, Lörincz A, Buzsáki G. Physiological patterns in the hippocampo-entorhinal cortex system. Hippocampus 2000; 10:457-65.

[32] Clark RE, Zola SM, Squire LR. Impaired recognition memory in rats after damage to the hippocampus. J Neurosci 2000;20:8853-60. 
[33] Cohen NJ, Eichenbaum H. Memory, Amnesia, and the Hippocampal System. Cambridge, MA: MIT Press, 1993.

[34] Cohen NJ, Shapiro M. Minding the general memory store: further consideration of the role of the hippocampus in memory. Behav Brian Sci 1985;8:498-9.

[35] Cohen NJ, Squire LR. Preserved learning and retention of pattern-analyzing skill in amnesia: dissociation of knowing how and knowing that. Science 1980;210:207-10.

[36] Corkin S. Acquisition of motor skill after bilateral medial temporal-lobe excision. Neuropsychologia 1968;6:255-65.

[37] Corkin S, Amaral DG, González RG, Johnson KA, Hyman BT. H.M.'s medial temporal lobe lesion: findings from magnetic resonance imaging. J Neurosci 1997;17:3864-979.

[38] Cressant A, Muller RU, Poucet B. Failure of centrally placed objects to control firing fields of hippocampal place cells. J Neurosci 1997;17:2531-42.

[39] Czurkó A, Hirase H, Csicsvari J, Buzsaki G. Sustained activation of hippocampal pyramidal cells by 'space clamping' in a running wheel. Eur J Neurosci 1999;11:344-52.

[40] Davidson TL, McKernan MG, Jarrard LE. Hippocampal lesions do not impair negative patterning: a challenge to configural association theory. Behav Neurosci 1993;107:22734.

[41] Day LB, Weisend M, Sutherland RJ, Schallert T. The hippocampus is not necessary for a place response but may be necessary for pliancy. Behav Neurosci 1999;113:914-24.

[42] Dember WN, Richman CL, editors. Spontaneous Alternation Behavior. New York: Springer, 1989.

[43] Desimone R. Neural mechanisms for visual memory and their role in attention. Proc Natl Acad Sci USA 1996;93:13494-9.

[44] Douglas RJ. The hippocampus and behavior. Psychol Bull 1967;67:416-42.

[45] Dudchenko PA, Wood ER, Eichenbaum H. Neurotoxic hippocampal lesions have no effect on odor span and little effect on odor recognition memory but produce significant impairments on spatial span, recognition, and alternation. J Neurosci 2000;20:2964-77.

[46] Eichenbaum H. Is the rodent hippocampus just for 'place'? Curr Opin Neurobiol 1996;6:187-95.

[47] Eichenbaum H. The hippocampus and mechanisms of declarative memory. Behav Brain Res 1999;103:123-33.

[48] Eichenbaum H, Kuperstein M, Fagan A, Nagode J. Cue-sampling and goal-approach correlates of hippocampal unit activity in rats performing an odor-discrimination task. J Neurosci 1987;7:716-32.

[49] Eichenbaum H, Stewart C, Morris RGM. Hippocampal representation in place learning. J Neurosci 1990;10:3531-42.

[50] Ekstrom AD, Meltzer JA, McNaughton BL, Barnes CA. Reactivation of recent hippocampal neural ensemble patterns does not require NMDA receptor dependent encoding. Soc Neurosci Abstr 2000;26:981.

[51] Ennaceur A, Delacour J. A new one-trial test for neurobiological studies of memory in rats. 1: Behavioral data. Behav Brain Res 1988;31:47-59.

[52] Fanselow MS. Contextual fear, gestalt memories, and the hippocampus. Behav Brain Res 2000;110:73-81.

[53] Foster DJ, Morris RGM, Dayan P. A model of hippocampally dependent navigation using the temporal difference learning rule. Hippocampus 2000;10:1-6.

[54] Frank LM, Brown EN, Wilson M. Trajectory encoding in the hippocampus and entorhinal cortex. Neuron 2000;27:169-78.

[55] Fuster JM. The Prefrontal Cortex: Anatomy, Physiology, and Neuropsychology of the Frontal Lobe, third ed. LippincottRaven, 1997.

[56] Gaffan D. Loss of recognition memory in rats with lesions of the fornix. Neuropsychologia 1972;10:327-41.
[57] Gaffan D, Sanders RC, Gaffan EA, Harrison S, Shields C, Owen MJ. Effects of fornix transection upon associative memory in monkeys: role of the hippocampus in learned actions. Q J Exp Psychol 1984;36B:173-221.

[58] Gallagher M, Holland PC. Preserved configural learning and spatial learning impairment in rats with hippocampal damage. Hippocampus 1992;2:81-8.

[59] Gallistel CR. The Organization of Learning. Cambridge, MA: MIT Press, 1990.

[60] Georges-francois P, Rolls ET, Robertson RG. Spatial view cells in the primate hippocampus: allocentric view not head direction or eye position or place. Cereb Cortex 1999;9:197-212.

[61] Gerrard JL, Cowen SL, Kudrimoti HS, Rosenzweig ES, Redish $\mathrm{AD}$, Barnes CA, McNaughton BL. Equivalent reactivation of hippocampal memory traces for a novel experience in young adult and aged rats. Soc Neurosci Abstr 2000;26:981.

[62] Gerrard JL, Kudrimoti HS, Barnes CA, McNaughton BL. Effects of aging on dynamics of hippocampal memory reactivation during sharp-waves. Soc Neurosci Abstr 1998;24:932.

[63] Gewirtz JC, McNish KA, Davis M. Is the hippocampus necessary for contextual fear conditioning. Behav Brain Res 2000;110:83-95.

[64] Goldman-Rakic PS, Funahashi S, Bruce CJ. Neocortical memory circuits. Cold Spring Harbor Symp Quant Biol 1990;LV:1025-38.

[65] Good M, de Hoz L, Morris RGM. Contingent versus incidental context processing during conditioning: dissociation after excitotoxic hippocampal plus dentate gyrus lesions. Hippocampus 1998;8:147-59.

[66] Good M, Honey RC. Conditioning and contextual retrieval in hippocampal rats. Behav Neurosci 1991;105:499-509.

[67] Gothard KM, Skaggs WE, McNaughton BL. Dynamics of mismatch correction in the hippocampal ensemble code for space: interaction between path integration and environmental cues. J Neurosci 1996;16:8027-40.

[68] Graybiel AM. Building action repertoires: memory and learning functions of the basal ganglia. Curr Opin Neurobiol 1995;5:733-41.

[69] Hampson RE, Heyser CJ, Deadwyler SA. Hippocampal cell firing correlates of delayed-match-to-sample performance in the rat. Behav Neurosci 1993;107:715-39.

[70] Hampson RE, Jarrard LE, Deadwyler SA. Effects of ibotenate hippocampal and extrahippocampal destruction on delayedmatch and -nonmatch-to-sample behavior in rats. J Neurosci 1999; 19:1492-507.

[71] Hampson RE, Simeral JD, Deadwyler SA. Distribution of spatial and nonspatial information in dorsal hippocampus. Nature 1999;402:610-4.

[72] Hartley T, Burgess N, Lever C, Cacucci F, O'Keefe J. Modeling place fields in terms of the cortical inputs to the hippocampus. Hippocampus 2000;10:369-79.

[73] Hasselmo ME. Acetylcholine and learning in a cortical associative memory. Neural Comput 1993;5:32-44.

[74] Hasselmo ME, Bower JM. Acetylcholine and memory. Trends Neurosci 1993;16:218-22.

[75] Hasselmo ME, Schnell E. Laminar selectivity of the cholinergic suppression of synaptic transmission in rat hippocampal region CA1: computational modeling and brain slice physiology. J Neurosci 1994;14:3898-914.

[76] Hasselmo ME, Wyble BP, Wallenstein GV. Retrieval of episodic memories: role of cholinergic and GABAergic modulation in the hippocampus. Hippocampus 1996;6:693-708.

[77] Hertz J, Krogh A, Palmer RG. Introduction to the Theory of Neural Computation. Reading, MA: Addison-Wesley, 1991.

[78] Hikosaka O, Nakahara H, Rand MK, Sakai K, Lu X, Nakamura K, Miyachi S, Doya K. Parallel neural networks for learning sequential procedures. Trends Neurosci 1999;22:46471. 
[79] Hill AJ. First occurrence of hippocampal spatial firing in a new environment. Exp Neurol 1978;62:282-97.

[80] Hirsh R. The hippocampus and contextual retrieval of information from memory: a theory. Behav Biol 1974;12:421-44.

[81] Hölscher C, Anwyl R, Rowan MJ. Stimulation on the positive phase of hippocampal theta rhythm induces long-term potentiation that can be depotentiated by stimulation on the negative phase in area CA1 in vivo. J Neurosci 1997;17:6470-7.

[82] Honey RC, Good M. Selective hippocampal lesions abolish the contextual specificity of latent inhibition and of conditioning. Behav Neurosci 1993;107:23-33.

[83] Hopfield JJ. Neural networks and physical systems with emergent collective computational abilities. Proc Natl Acad Sci USA 1982;79:2554-8.

[84] Jarrard LE. On the hippocampus, time, and interference. Behav Brain Sci 1985;8:503-4.

[85] Jarrard LE. On the role of the hippocampus in learning and memory in the rat. Behav Neural Biol 1993;60:9-26.

[86] Káli S, Dayan P. The involvement of recurrent connections in area CA3 in establishing the properties of place fields: a model. J Neurosci 2000;20:7463-77.

[87] Kentros C, Hargreaves E, Hawkins RD, Kandel ER, Shapiro M, Muller RV. Abolition of long-term stability of new hippocampal place cell maps by NMDA receptor blockade. Science 1998;280:2121-6.

[88] Kesner RP, Bolland BL, Dakis M. Memory for spatial locations, motor responses, and objects: triple dissociation among the hippocampus, caudate nucleus, and extrastriate visual cortex. Exp Brain Res 1993;93:462-70.

[89] Knierim JJ, Kudrimoti HS, McNaughton BL. Interactions between idiothetic cues and external landmarks in the control of place cells and head direction cells. J Neurophysiol 1998;80:425-46.

[90] Knierim JJ, McNaughton BL. Hippocampal place-cell firing during movement in three-dimensional space. J Neurophysiol 2001;85:105-16.

[91] Knowlton BJ, Mangels JA, Squire LR. A neostriatal habit learning system in humans. Science 1996;273:1399-402.

[92] Koerner A, Thomas MJ, Weisend MP, Sutherland RJ. Hippocampal-dependent memory consolidation: an evaluation of three hypotheses. Soc Neurosci Abstr 1996;22:1118.

[93] Kubie JL, Ranck JB. Sensory-behavioral correlates in individual hippocampus neurons in three situations: space and context. In: Seifert W, editor. Neurobiology of the Hippocampus. New York: Academic Press, 1983:433-47.

[94] Kudrimoti HS, Barnes CA, McNaughton BL. Reactivation of hippocampal cell assemblies: effects of behavioral state, experience, and EEG dynamics. J Neurosci 1999;19:4090-101.

[95] Lavenex P, Amaral DG. Hippocampal-neocortical interaction: a hierarchy of associativity. Hippocampus 2000;10:420-30.

[96] Louie K, Wilson MA. Temporally structured replay of awake hippocampal ensemble activity during rapid eye movement sleep. Neuron 2001;29.

[97] Luria AR. The Working Brain: An Introduction to Neuropsychology. New York: Basic Books, 1973 Translated by B. Haigh.

[98] Maaswinkel H, Jarrard LE, Whishaw IQ. Hippocampectomized rats are impaired in homing by path integration. Hippocampus 1999;9:553-61.

[99] Malenka RC. LTP and LTD: dynamic and interactive processes of synaptic plasticity. Neuroscientist 1995;1:35-42.

[100] Markus EJ, Barnes CA, McNaughton BL, Gladden VL, Skaggs WE. Spatial information content and reliability of hippocampal CA1 neurons: effects of visual input. Hippocampus 1994;4:410-21.

[101] Markus EJ, Qin Y, Leonard B, Skaggs WE, McNaughton BL, Barnes CA. Interactions between location and task affect the spatial and directional firing of hippocampal neurons. J Neurosci 1995;15:7079-94.
[102] Marr D. A theory of cerebellar cortex. J Physiol 1969;202:43770.

[103] Marr D. Simple memory: a theory of archicortex. Phil Trans Roy Soc London 1971;262:23-81.

[104] McClelland JL, McNaughton BL, O'Reilly RC. Why there are complementary learning systems in the hippocampus and neocortex: insights from the successes and failures of connectionist models of learning and memory. Psychol Rev 1995;102:419-57.

[105] McDonald RJ, White NM. Parallel information processing in the water maze: evidence for independent memory systems involving dorsal striatum and hippocampus. Behav Neural Biol 1994;61:260-70.

[106] McGaugh JL. Time-dependent processes in memory storage. Science 1966;153:1351-8.

[107] McNaughton BL. The mechanism of expression of long-term enhancement of hippocampal synapses: current issues and theoretical implications. Annu Rev Physiol 1993;55:375-96.

[108] McNaughton BL, Barnes CA, Gerrard JL, Gothard K, Jung MW, Knierim JJ, Kudrimoti H, Qin Y, Skaggs WE, Suster M, Weaver KL. Deciphering the hippocampal polyglot: the hippocampus as a path integration system. J Exp Biol 1996;199:173-86.

[109] McNaughton BL, Barnes CA, O'Keefe J. The contributions of position, direction, and velocity to single unit activity in the hippocampus of freely-moving rats. Exp Brain Res 1983;52:419.

[110] McNaughton BL, Morris RGM. Hippocampal synaptic enhancement and information storage within a distributed memory system. Trends Neurosci 1987;10:408-15.

[111] McNaughton BL, Nadel L. Hebb-Marr networks and the neurobiological representation of action in space. In: Gluck MA, Rumelhart DE, editors. Neuroscience and Connectionist Theory. Hillsdale, NJ: Erlbaum, 1990:1-63.

[112] Mehta MR, Barnes CA, McNaughton BL. Experience-dependent, asymmetric expansion of hippocampal place fields. Proc Natl Acad Sci USA 1997;94:8918-21.

[113] Meunier M, Bachevalier J, Mishkin M, Murray EA. Effects on visual recognition of combined and separate ablations of the entorhinal and perirhinal cortex in rhesus monkeys. J Neurosci 1993;13:5418-32.

[114] Miller EK, Desimone R. Parallel neuronal mechanisms for short-term memory. Science 1994;263:520-2.

[115] Miller EK, Li L, Desimone R. A neural mechanism for working and recognition memory in inferior temporal cortex@ Science 1991;254:1377-9.

[116] Milner B. Memory and the medial temporal regions of the brain. In: Pribram KH, Broadbent DE, editors. Biology of Memory. New York: Academic Press, 1970:29-50.

[117] Milner B, Corkin S, Teuber H-L. Further analysis of the hippocampal amnesia syndrome: 14-year follow-up study of H.M. Neuropsychologia 1968;6:215-34.

[118] Minsky M, Papert S. Perceptrons. Cambridge, MA: MIT Press, 1969.

[119] Mishkin M. Memory in monkeys severly impaired by combined but not separate removal of amygdala and hippocampus. Nature 1978;273:297-8.

[120] Mishkin M, Appenzeller T. The anatomy of memory. Sci Am 1987;256:80-9.

[121] Mishkin M, Malamut B, Bachevalier J. Memories and habits: two neural systems. In: Lynch G, McGaugh JL, Weinberger NM, editors. Neurobiology of Learning and Memory. New York: Guilford, 1984:65-77.

[122] Mittelstaedt H, Mittelstaedt M-L. Homing by path integration. In: Papi F, Wallraff HG, editors. Avian Navigation. New York: Springer, 1982:290-7. 
[123] Mizumori SJY, Ward KE, Lavoie AM. Medial septal modulation of entorhinal single unit activity in anesthetized and freely moving rats. Brain Res 1992;570:188-97.

[124] Mogenson GJ, Jones DL, Yim CY. From motivation to action: functional interface between the limbic system and the motor system. Prog Neurobiol 1980;14:69-97.

[125] Morris RGM. Spatial localization does not require the presence of local cues. Learn Motiv 1981;12:239-60.

[126] Morris RGM, Garrud P, Rawlins JNP, O'Keefe J. Place navigation impaired in rats with hippocampal lesions. Nature 1982;297:681-3

[127] Muir GM, Bilkey DK. Instability in the place field location of hippocampal place cells after lesions centered on the perirhinal cortex. J Neurosci 2001;21:4016-25.

[128] Muller RU, Bostock E, Taube JS, Kubie JL. On the directional firing properties of hippocampal place cells. J Neurosci 1994;14:7235-51.

[129] Muller RU, Kubie JL. The effects of changes in the environment on the spatial firing of hippocampal complex-spike cells. $\mathbf{J}$ Neurosci 1987;7:1951-68.

[130] Muller RU, Kubie JL, Ranck JB. Spatial firing patterns of hippocampal complex-spike cells in a fixed environment. J Neurosci 1987;7:1935-50.

[131] Mumby DG, Astur RS, Weisend MP, Sutherland RJ. Retrograde amnesia and selective damage to the hippocampal formation: memory for places and object discriminations. Behav Brain Res 1999;106:97-107.

[132] Mumby DG, Wood ER, Duva CA, Kornecook TJ, Pinel JPJ, Phillips AG. Ischemia-induced object-recognition deficits in rats are attenuated by hippocampal ablation before or soon after ischemia. Behav Neurosci 1996;110:266-81.

[133] Murray EA. Medial temporal lobe structures contributing to recognition memory: the amygdaloid complex versus the rhinal cortex. In: Aggleton JP, editor. The Amygdala: Neurobiological Aspects of Emotion, Memory, and Mental Dysfunction. New York: Wiley, 1992:453-70.

[134] Murray EA, Gaffan D, Mishkin M. Neural substrates of visual stimulus-stimulus association in rhesus monkeys. J Neurosci 1993;13:4549-61.

[135] Murray EA, Mishkin M. Severe tactual as well as visual memory deficits follow combined removal of the amygdala and hippocampus in monkeys. J Neurosci 1984;4:2565-80.

[136] Murray EA, Mishkin M. Visual recognition in monkeys following rhinal cortical ablations combined with either amygdalectomy or hippocampectomy. J Neurosci 1986;6:1991-2003.

[137] Murray EA, Mishkin M. Object recognition and location memory in monkeys with excitotoxic lesions of the amygdala and hippocampus. J Neurosci 1998;18:6568-82.

[138] Myrher T. Retroactive memory of a visual discrimination task in the rat: role of temporal-entorhinal cortices and their connections. Exp Brain Res 1991;84:517-24.

[139] Nádasdy Z, Hirase H, Czurkó A, Csicsvari J, Buzsáki G. Replay and time compression of recurring spike sequences in the hippocampus. J Neurosci 1999;19:9497-507.

[140] Nadel L. Multiple memory systems: what and why, an update. In: Schacter DL, Tulving E, editors. Memory Systems 1994. Cambridge, MA: MIT Press, 1994:39-64.

[141] Nadel L. The role of the hippocampus in declarative memory: a commentary on Zola-Morgan, Squire, and Ramus 1994. Hippocampus 1995;259:232-4.

[142] Nadel L, Eichenbaum H. Introduction to the special issue on place cells. Hippocampus 1999;9:341-5.

[143] Nadel L, Moscovitch M. Memory consolidation, retrograde amnesia and the hippocampal complex. Curr Opin Neurobiol 1997;7:217-27.

[144] Nadel L, O'Keefe J, Black A. Slam on the brakes: a critique of Altman, Brunner, and Bayer's response-inhibition model of hippocampal function. Behav Biol 1975;14:151-62.
[145] Nadel L, Willner J. Context and conditioning: a place for space. Physiol Psychol 1980;8:218-28.

[146] O'Keefe J. Computations the hippocampus might perform. In: Nadel L, Cooper L, Culicover P, Harnish RM, editors. Neural Connections, Mental Computation. Cambridge, MA: MIT Press, 1989:225-84.

[147] O'Keefe J. Do hippocampal pyramidal cells signal non-spatial as well as spatial information. Hippocampus 1999;9:352-65.

[148] O'Keefe J, Conway DH. Hippocampal place units in the freely moving rat: why they fire where they fire. Exp Brain Res 1978;31:573-90.

[149] O'Keefe J, Dostrovsky J. The hippocampus as a spatial map. Preliminary evidence from unit activity in the freely moving rat. Brain Res 1971;34:171-5.

[150] O'Keefe J, Nadel L. The Hippocampus as a Cognitive Map. Oxford: Clarendon Press, 1978.

[151] O'Keefe J, Recce M. Phase relationship between hippocampal place units and the EEG theta-rhythm. Hippocampus 1993;3:317-30.

[152] O'Keefe J, Speakman A. Single-unit activity in the rat hippocampus during a spatial memory task. Exp Brain Res 1987;68:1-27.

[153] Olton DS, Becker JT, Handelmann GE. Hippocampus, space, and memory. Behav Brain Sci 1979;2:313-22 See also commentary and response, pp. 323-366.

[154] Olton DS, Branch M, Best PJ. Spatial correlates of hippocampal unit activity. Exp Neurol 1978;58:387-409.

[155] Olton DS, Samuelson RJ. Remembrance of places passed: spatial memory in rats. J Exp Psychol: Anim Behav Proces 1976;2:97-116.

[156] O'Reilly RC, McClelland JL. Hippocampal conjunctive encoding, storage, and recall: avoiding a trade-off. Hippocampus 1994;4:661-82.

[157] Otto T, Eichenbaum H. Neuronal activity in the hippocampus during delayed non-match to sample performance in rats: evidence for hippocampal processing in recognition memory. Hippocampus 1992;2:323-34.

[158] Packard MG, Hirsh R, White NM. Differential effects of fornix and caudate nucleus lesions on two radial maze tasks: evidence for multiple memory systems. J Neurosci 1989;9:1465-72.

[159] Packard MG, McGaugh JL. Double dissociation of fornix and caudate nucleus lesions on acquisition of two water maze tasks: further evidence for multiple memory systems. Behav Neurosci 1992;106:439-46.

[160] Packard MG, McGaugh JL. Inactivation of hippocampus or caudate nucleus with lidocaine differentially affects expression of place and response learning. Neurobiol Learn Mem 1996;65:65-72.

[161] Pavlides C, Winson J. Influences of hippocampal place cell firing in the awake state on the activity of these cells during subsequent sleep episodes. J Neurosci 1989;9:2907-18.

[162] Pearce JM, Roberts ADL, Good M. Hippocampal lesions disrupt navigation based on cognitive maps but not heading vectors. Nature 1998;396:75-7.

[163] Pennartz CMA, Groenewegen HJ, Lopes da Silva FH. The nucleus accumbens as a complex of functionally distinct neuronal ensembles: an integration of behavioural, electrophysiological, and anatomical data. Prog Neurobiol 1994;42:719-61.

[164] Poe G, Nitz DA, McNaughton BL, Barnes CA. Experience-dependent phase-reversal of hippocampal neuron firing during REM sleep. Brain Res 2000;855:176-80.

[165] Qin YL, McNaughton BL, Skaggs WE, Barnes CA. Memory reprocessing in corticocortical and hippocampocortical neuronal ensembles. Philos Trans Roy Soc London 1997;B352:1525-33.

[166] Quirk GJ, Muller RU, Kubie JL. The firing of hippocampal place cells in the dark depends on the rat's recent experience. $\mathbf{J}$ Neurosci 1990;10:2008-17. 
[167] Quirk GJ, Muller RU, Kubie JL, Ranck JB. The positional firing properties of medial entorhinal neurons: description and comparison with hippocampal place cells. J Neurosci 1992;12:1945-63.

[168] Ramón y Cajal S. The Structure of Ammon's Horn. Springfield, IL: Thomas, 1968 Translated by L.M. Kraft.

[169] Ranck JB. Studies on single neurons in dorsal hippocampus formation and septum in unrestrained rats. I. Behavioral correlates and firing repertoires. Exp Neurol 1973;41:461-555.

[170] Rawlins JNP. Associations across time: the hippocampus as a temporary memory store. Behav Brain Sci 1985;8:479-96 see also commentary and response, pp. 497-528.

[171] Recce M, Harris KD. Memory for places: A navigational model in support of Marr's theory of hippocampal function. Hippocampus 1996;6:735-48.

[172] Redish AD. Beyond the cognitive map: contributions to a computational neuroscience theory of rodent navigation. $\mathrm{PhD}$ thesis, Carnegie Mellon University, 1997.

[173] Redish AD. Beyond the Cognitive Map: From Place Cells to Episodic Memory. Cambridge, MA: MIT Press, 1999.

[174] Redish AD, McNaughton BL, Barnes CA. Place cell firing shows an inertia-like process. Neurocomputing 2000;32$33: 235-41$

[175] Redish AD, Rosenzweig ES, Bohanick JD, McNaughton BL, Barnes CA. Dynamics of hippocampal ensemble realignment: time versus space. J Neurosci 2000;20:9289-309.

[176] Redish AD, Touretzky DS. Modeling interactions of the rat's place and head direction systems. In: Touretzky DS, Mozer MC, Hasselmo ME, editors. Advances in Neural Information Processing Systems 8. Cambridge, MA: MIT Press, 1996:61-71

[177] Redish AD, Touretzky DS. Cognitive maps beyond the hippocampus. Hippocampus 1997;7:15-35.

[178] Redish AD, Touretzky DS. The role of the hippocampus in solving the Morris water maze. Neural Comput 1998;10:73111.

[179] Redish AD, Touretzky DS. Separating hippocampal maps. In: Burgess N, Jeffery K, O'Keefe J, editors. Spatial Functions of the Hippocampal Formation and the Parietal Cortex. New York: Oxford University Press, 1998:203-19.

[180] Rempel-Clower NL, Zola SM, Squire LR, Amaral DG. Three cases of enduring memory impairment after bilateral damage limited to the hippocampal formation. $\mathbf{J}$ Neurosci 1996;16:5233-55.

[181] Rettenmaier BB, White AM, Doboli S, Minai A, Best PJ. Place fields of hippocampal pyramidal cells in rats show hysteresis. Soc Neurosci Abstr 1999;25:1380.

[182] Ribot TA. Diseases of Memory, 1882. Reprinted in Significant Contributions to the History of Psychology, Series C, Medical Psychology, vol. 1. Washington DC: University Publications of America, 1977.

[183] Rioult-Pedotti M-S, Friedman D, Donoghue JP. Learning-induced LTP in neocortex. Science 2000;290:533-6.

[184] Rolls ET. The representation and storage of information in neuronal networks in the primate cerebral cortex and hippocampus. In: Durbin R, Miall C, Mitchison G, editors. The Computing Neuron. Reading, MA: Addison-Wesley, 1989:125-59.

[185] Rolls ET. A theory of hippocampal function in memory. Hippocampus 1996;6:601-20.

[186] Rolls ET. Spatial view cells and the representation of place in the primate hippocampus. Hippocampus 1999;9:467-80.

[187] Rolls ET, O'Mara SM. View responsive neurons in the primate hippocampal complex. Hippocampus 1995;5:409-24.

[188] Rosenzweig ES, Ekstrom AD, Redish AD, McNaughton BL, Barnes CA. Phase precession as an experience-independent process: hippocampal pyramidal cell phase precession in a novel environment and under NMDA-receptor blockade. Soc Neurosci Abstr 2000;26:982.
[189] Rotenberg A, Abel T, Hawkins RD, Kandel ER, Muller RU. Parallel instabilities of long-term potentiation, place cells, and learning caused by decreased protein kinase A activity. J Neurosci 2000;20:8096-102.

[190] Rotenberg A, Mayford M, Hawkins RD, Kandel ER, Muller RU. Mice expressing activated CaMKII lack low frequency LTP and do not form stable place cells in the CA1 region of the hippocampus. Cell 1996;87:1351-61.

[191] Rudy JW, Sutherland RJ. Configural asssociation theory and the hippocampal formation: an appraisal and reconfiguration. Hippocampus 1995;5:375-89.

[192] Saint-Cyr JA, Taylor AE, Nicholson K. Behavior and the basal ganglia. In: Weiner WJ, Lang AE, editors. Behavioral Neurology of Movement Disorders. New York: Raven Press, 1995:128.

[193] Sakurai Y. Cells in the rat auditory system have sensory delay correlates during the performance of an auditory working memory task. Behav Neurosci 1990;104:856-68.

[194] Sakurai Y. Hippocampal cells have behavioral correlates during the performance of an auditory working memory task in the rat. Behav Neurosci 1990;104:253-63.

[195] Sakurai Y. Involvement of auditory cortical and hippocampal neurons in auditory working memory and reference memory in the rat. J Neurosci 1994;14:2606-23.

[196] Samsonovich AV, McNaughton BL. Path integration and cognitive mapping in a continuous attractor neural network model. J Neurosci 1997;17:5900-20.

[197] Scoville WB. Amnesia after bilateral medial temporal-lobe excision: introduction to case H.M. Neuropsychologia 1968;6:211-3.

[198] Scoville WB, Milner B. Loss of recent memory after bilateral hippocampal lesions. J Neurol Neurosurg Psychiatry 1957;20:11-21.

[199] Shapiro ML, Eichenbaum H. Hippocampus as a memory map: synaptic plasticity and memory encoding by hippocampal neurons. Hippocampus 1999;9:365-84.

[200] Sharp PE. Computer simulation of hippocampal place cells. Psychobiology 1991;19:103-15.

[201] Sharp PE. Subicular cells generate similar firing patterns in two geometrically and visually distinctive environments: comparison with hippocampal place cells. Behav Brain Res 1997;85:71-92.

[202] Sharp PE, Blair HT, Etkin D, Tzanetos DB. Influences of vestibular and visual motion information on the spatial firing patterns of hippocampal place cells. J Neurosci 1995;15:17389.

[203] Sharp PE, Green C. Spatial correlates of firing patterns of single cells in the subiculum of the freely moving rat. J Neurosci 1994;14:2339-56.

[204] Sharp PE, Kubie JL, Muller RU. Firing properties of hippocampal neurons in a visually symmetrical environment: contributions of multiple sensory cues and mnemonic processes. J Neurosci 1990;10:3093-105.

[205] Shen B, McNaughton BL. Modeling the spontaneous reactivation of experience-specific hippocampal cell assembles during sleep. Hippocampus 1996;6:685-93.

[206] Skaggs WE, McNaughton BL. Replay of neuronal firing sequences in rat hippocampus during sleep following spatial experience. Science 1996;271:1870-3.

[207] Skaggs WE, McNaughton BL. Spatial firing properties of hippocampal CA1 populations in an environment containing two visually identical regions. J Neurosci 1998;18:8455-66.

[208] Skaggs WE, McNaughton BL, Wilson MA, Barnes CA. Theta phase precession in hippocampal neuronal populations and the compression of temporal sequences. Hippocampus 1996;6:14973.

[209] Smith C. Sleep states and memory processes. Behav Brain Res 1995;69:137-45. 
[210] Squire LR. Memory and Brain. New York: Oxford University Press, 1987.

[211] Squire LR. Memory and the hippocampus: a synthesis from findings with rats, monkeys, and humans. Psychol Rev 1992;99:195-231.

[212] Squire LR, Alvarez P. Retrograde amnesia and memory consolidation: a neurobiological perspective. Curr Opin Neurobiol 1995;5:169-77.

[213] Stanton ME. Multiple memory systems, development and conditioning. Behav Brain Res 2000;110:25-37.

[214] Staubli U, Fraser D, Kessler M, Lynch G. Studies on retrograde and anterograde amnesia of olfactory memory after denervation of the hippocampus by entorhinal cortex lesions. Behav Neural Biol 1986;46:432-44.

[215] Sutherland GR, McNaughton BL. Memory trace reactivation in hippocampal and neocortical neuronal ensembles. Curr Opin Neurobiol 2000;10:180-6.

[216] Sutherland RJ, Rudy JW. Configural association theory: the role of the hippocampal formation in learning, memory, and amnesia. Psychobiology 1989;17:129-44.

[217] Suzuki WA. The anatomy, physiology, and functions of the perirhinal cortex. Curr Opin Neurobiol 1996;6:179-86.

[218] Suzuki WA, Miller EK, Desimone R. Object and place memory in the macaque entorhinal cortex. J Neurophysiol 1997;78:106281.

[219] Tanila H. Hippocampal place cells can develop distinct representations of two visually identical environments. Hippocampus 1999;9:235-46.

[220] Tanila H, Shapiro M, Gallagher M, Eichenbaum H. Brain aging: changes in the nature of information coding by the hippocampus. J Neurosci 1997;17:5155-66.

[221] Tanila H, Sipilä P, Shapiro M, Eichenbaum H. Brain aging: impaired coding of novel environmental cues. J Neurosci 1997; 17:5167-74.

[222] Teng E, Squire LR. Memory for places learned long ago is intact after hippocampal damage. Nature 1999;400:675-7.

[223] Thompson LT, Best PJ. Place cells and silent cells in the hippocampus of freely-behaving rats. J Neurosci 1989;9:238290.

[224] Tolman EC. Cognitive maps in rats and men. Psychol Rev 1948;55:189-208.

[225] Touretzky DS, Redish AD. A theory of rodent navigation based on interacting representations of space. Hippocampus 1996;6:247-70.

[226] Trullier O, Wiener SI, Berthoz A, Meyer JA. Biologically based artificial navigation systems: review and prospects. Prog Neurobiol 1997;51:483-544.

[227] Tsodyks MV, Skaggs WE, Sejnowski TJ, McNaughton BL. Population dynamics and theta-rhythm phase precession of hippocampal place cell firing: a spiking neuron model. Hippocampus 1996;6:271-80.

[228] Van Hoesen GW. The parahippocampal gyrus: new observations regarding its cortical connections in the monkey. Trends Neurosci 1982;5:345-50.

[229] Vanderwolf CH. Limbic-diencephalic mechanisms of voluntary movement. Psychol Rev 1971;78:83-113.

[230] Wallenstein GV, Eichenbaum H, Hasselmo ME. The hippocampus as an associator of discontiguous events. Trends Neurosci 1998;21:317-23.

[231] Wan HS, Touretzky DS, Redish AD. A rodent navigation model that combines place code, head direction, and path integration information. Soc Neurosci Abstr 1994;20:1205.

[232] Whishaw IQ. Place learning in hippocampal rats and the path integration hypothesis. Neurosci Biobehav Rev 1998;22:209-20.

[233] Whishaw IQ, Cassel J-C, Jarrard LE. Rats with fimbria-fornix lesions display a place response in a swimming pool: a dissocia- tion between getting there and knowing where. J Neurosci 1995;15:5779-88.

[234] Whishaw IQ, Jarrard LE. Evidence for extrahippocampal involvement in place learning and hippocampal involvement in path integration. Hippocampus 1996;6:513-24.

[235] Whishaw IQ, Mittleman G. Visits to starts, routes, and places by rats (Rattus norvegicus). J Comp Psychol 1986;100:422-31.

[236] Whishaw IQ, Tomie JA. Acquisition and retention by hippocampal rats of simple, conditional, and configural tasks using tactile and olfactory cues: implications for hippocampal function. Behav Neurosci 1991;105:787-97.

[237] Whishaw IQ, Tomie JA. Rats with fimbria-fornix lesions can acquire and retain a visual-tactile transwitching (configural) task. Behav Neurosci 1995;109:607-12.

[238] Wible CG, Findling RL, Shapiro M, Lang EJ, Crane S, Olton DS. Mnemonic correlates of unit activity in the hippocampus. Brain Res 1986;399:97-110.

[239] Wiener SI, Paul CA, Eichenbaum H. Spatial and behavioral correlates of hippocampal neuronal activity. J Neurosci 1989;9:2737-83.

[240] Wiggs CL, Martin A. Properties and mechanisms of perceptual priming. Curr Opin Neurobiol 1998;8:227-33.

[241] Wilson MA, McNaughton BL. Reactivation of hippocampal ensemble memories during sleep. Science 1994;265:676-9.

[242] Witter MP. Organization of the entorhinal-hippocampal system: a review of current anatomical data. Hippocampus 1993;3:33-44.

[243] Witter MP, Groenewegen HJ, Lopes da Silva FH, Lohman AHM. Functional organization of the extrinsic and intrinsic circuitry of the parahippocampal region. Prog Neurobiol 1989;33:161-253.

[244] Witter MP, Naber PA, van Haeften T, Machielsen WCM, Rombouts SARB, Barkhof F, Scheltens P, Lopes da Silva FH. Cortico-hippocampal communication by way of parallel parahippocampal-subicular pathways. Hippocampus 2000;10:398-410.

[245] Witter MP, Ostendorf RH, Groenwegen HJ. Heterogeneity in the dorsal subiculum of the rat. Distinct neuronal zones project to different cortical and subcortical targets. Eur J Neurosci 1990;2:718-25.

[246] Wood ER, Dudchenko PA, Eichenbaum H. The global record of memory in hippocampal neuronal activity. Nature 1999;397:613-6.

[247] Wood ER, Dudchenko PA, Robitsek RJ, Eichenbaum H. Hippocampal neurons encode information about different types of memory episodes occurring in the same location. Neuron 2000;27:623-33.

[248] Wood ER, Mumby DG, Pinel JPJ, Phillips AG. Impaired object recognition memory in rats following ischemia-induced damage to the hippocampus. Behav Neurosci 1996;107:51-62.

[249] Ylinen A, Bragin A, Nadasdy Z, Jando G, Szabo I, Sik A, Buzsáki G. Sharp wave-associated high-frequency oscillation $(200 \mathrm{~Hz})$ in the intact hippocampus: network and intracellular mechanisms. J Neurosci 1995;15:30-46.

[250] Young BJ, Fox GD, Eichenbaum H. Correlates of hippocampal complex-spike cell activity in rats performing a nonspatial radial maze task. J Neurosci 1994;14:6553-63.

[251] Zipser D. A computational model of hippocampal place fields. Behav Neurosci 1985;99:1006-18.

[252] Zipser D. Recurrent network model of the neural mechanism of short-term active memory. Neural Comput 1991;3:179-93.

[253] Zola SM, Squire LR, Teng E, Stefanacci L, Buffalo EA, Clark RE. Impaired recognition memory in monkeys after damage limited to the hippocampal region. J Neurosci 2000;20:451-63.

[254] Zola-Morgan S, Squire LR. The primate hippocampal formation: evidence for a time-limited role in memory storage. Science 1990;250:288-90.

[255] Zola-Morgan S, Squire LR. Neuroanatomy of memory. Ann Rev Neurosci 1993;16:547-63. 
[256] Zola-Morgan S, Squire LR, Amaral DG. Human amnesia and the medial temporal region: enduring memory impairment following a bilateral lesion limited to field CA1 of the hippocampus. J Neurosci 1986;6:2950-67.

[257] Zola-Morgan S, Squire LR, Amaral DG. Lesions of the amygdala that spare adjacent cortical regions do not impair memory or exacerbate the impairment following lesions of the hippocampal formation. J Neurosci 1989;9:1922-36.
[258] Zola-Morgan S, Squire LR, Amaral DG, Suzuki WA. Lesions of perirhinal and parahippocampal cortex that spare the amygdala and hippocampal formation produce severe memory impairment. J Neurosci 1989;9:4355-70.

[259] Zola-Morgan S, Squire LR, Ramus SJ. Severity of memory impairment in monkeys as a function of locus and extent of damage within the medial temporal lobe memory system. Hippocampus 1994;4:483-95. 